\title{
"Fungus ball" obstructivos en trasplantados renales
}

\author{
Ballesteros Sampol JJ.
}

Unidad de Trasplante Renal del Hospital de la Esperanza. Barcelona.

\section{Actas Urol Esp. 2008;32(2):267}

$\mathrm{S}^{\mathrm{e}}$ e presentan dos casos de trasplantados renales que presentaron clínica obstructiva (oligoanuria, dolor en la zona del injerto e insuficiencia renal). Aunque la candidiasis no es rara en pacintes inmunodeprimidos, la obstrucción de la vía urinaria por acúmulos de "hifas" ha constituido el $9,5 \%$ de tales casos (sobre 466 T.R.) y, a su vez, el 0,4\% de las complicaciones de los trasplantados que han requerido manipulación instrumental o quirúrgica para su solución.

El diagnóstico se logró por nefrostografía tras nefrostomía derivativa inicial y ureteropielografia retrógrada (Figs. 1 y 2) y el hallazgo de las características "hifas" en orina teñidas con plata metenamina (Figs. 3 y 4, a mayor aumento).

Correspondencia autor: Dr. J.J. Ballesteros Sampol Unidad de Trasplante Renal. Hospital de la Esperanza Sant Josep de La Muntanya, 1208024 Barcelona Tel.: 933674100

E-mail: jballesteros@imas.imim.es Información artículo: Imágenes en Urologia Trabajo recibido: octubre 2006

Trabajo aceptado: noviembre 2006

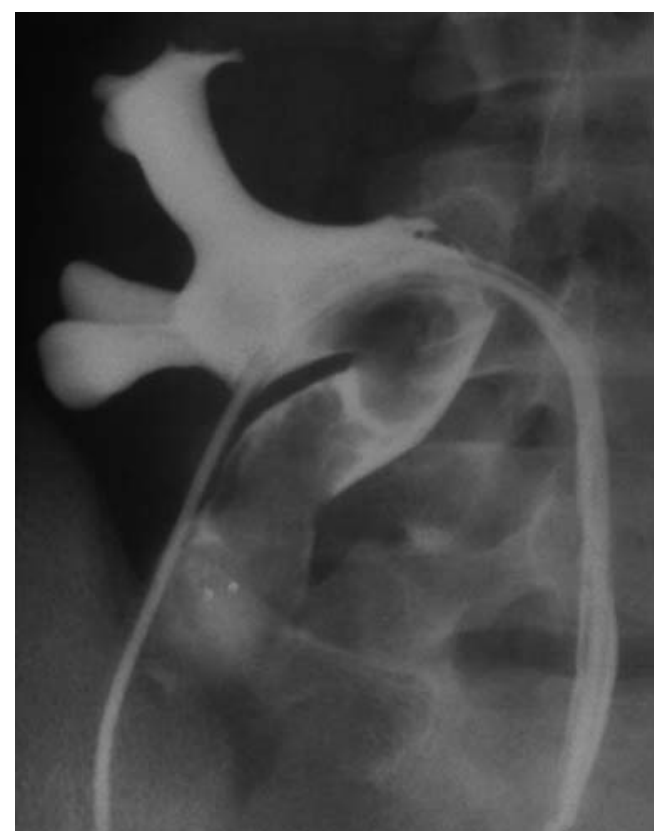

FIGURA 1

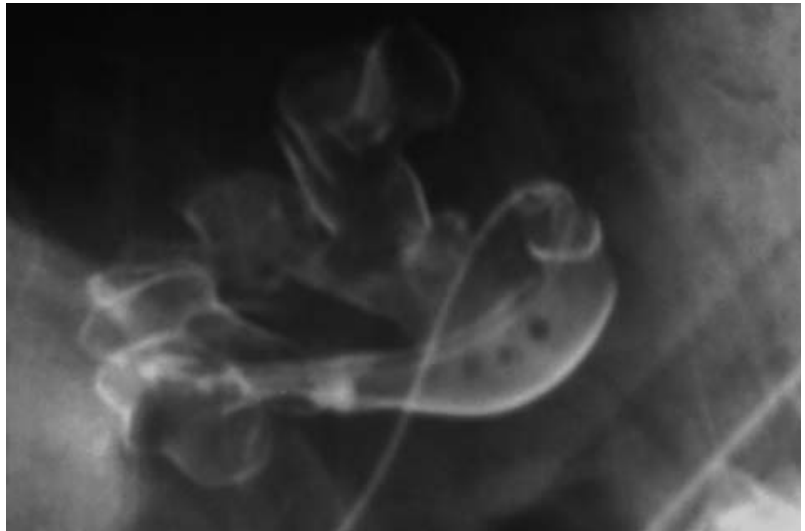

FIGURA 2
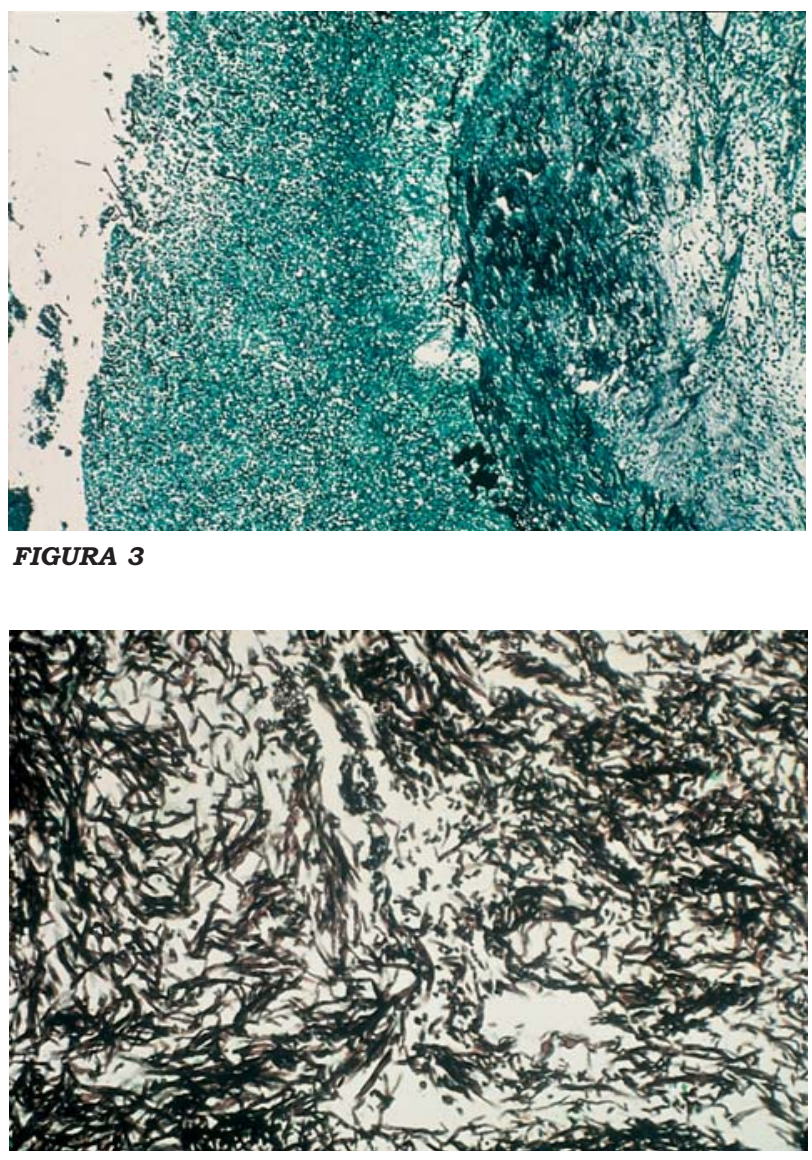

FIGURA 4 